\title{
A case of sporadic Creutzfeldt - Jakob disease and discussion on diagnostic biomarkers
}

\section{Boala Creutzfeldt - Jakob sporadică: prezentare de caz şi discuții asupra biomarkerilor diagnostici}

\author{
Corina Roman-Filip ${ }^{1,2^{*}}$, Aurelian Ungureanu ${ }^{1}$, Dan Filip ${ }^{1}$, Eugen Radu ${ }^{3}$, \\ Ioan-Sorin Zaharie ${ }^{3}$ \\ 1. Neurology Department, Emergency Clinical County Hospital Sibiu \\ 2. "Lucian Blaga" University Sibiu \\ 3. Pathology Department, Emergency Clinical County Hospital Sibiu, Romania
}

\begin{abstract}
Creutzfeldt - Jakob disease (CJD) is a rare neurodegenerative disease caused by prions, characterized by a progressive dementia with rapid onset, psychiatric and neurologic symptoms (myoclonus, cerebellar, pyramidal, extrapyramidal and visual signs), with an invariable course to exitus. There are three general forms: sporadic or spontaneous, genetic or familial, and acquired form, including a variant form of CJD. The diagnosis can be confirmed only by histological examination of brain tissue, showing non-inflammatory spongiform changes and neuronal loss. We present the case of a 64 years old male who was admitted in our department for a rapidly progressive cognitive decline, hallucinations and myoclonus. Autopsy brain histology confirmed the diagnosis showing incipient spongiform vacuolization and astrogliosis. This paper illustrates a very rapid course of a sporadic CJD with discussion upon literature regarding the laboratory and pathology biomarkers of diagnosis.
\end{abstract}

Keywords: Creutzfeldt - Jakob disease, prions, biomarkers.

\section{Rezumat}

Boala Creutzfeldt - Jakob (CJD) este o boală rară neurodegenerativă, cauzată de prioni, caracterizată printr-o demență progresivă cu evoluție rapidă, semne şi simptome neurologice (mioclonii, semne cerebeloase, piramidale, extrapiramidale şi vizuale) şi psihiatrice, cu evoluție invariabilă spre deces. Sunt recunoscute trei forme: sporadică sau spontană, genetică sau familială, şi forma dobândită, inclusiv CJD variantă. Diagnosticul poate fi confirmat doar prin examenul histopatologic al țesutului cerebral, care prezintă modificări spongiforme non-inflamatorii şi pierdere neuronală masivă. În lucrarea de față prezentăm cazul unui barbat de 64 de ani, care a fost internat în departamentul nostru pentru un declin cognitiv rapid progresiv, halucinații şi mioclonii care a decedat la scurt timp de la internare. Autopsia a confirmat diagnosticul de CJD, de remarcat fiind vacuolizarea spongiformă incipientă şi astroglioză. Aceasta lucrare ilustrează o evoluție foarte rapidă a unei CJD sporadice cu discuții pe marginea literaturii de specialitate cu privire la utilitatea biomarkerilor diagnostici specifici.

Cuvinte cheie: Boală Creutzfeldt - Jakob, prioni, biomarkeri.

Received: 17 $7^{\text {th }}$ December 2012; Accepted: $18^{\text {th }}$ April 2013; Published: $15^{\text {th }}$ June 2013.

${ }^{*}$ Corresponding author: Dr. Corina Roman-Filip, Neurology Dept., Sibiu Emergency Clinical County Hospital, Pompeiu Onofreiu St. 2-4, 550166. E-mail: corinaromanf@yahoo.com 


\section{Introduction}

Creutzfeldt - Jakob Disease (CJD) is a rapidly progressive spongiform neurodegenerative disorder, with an incidence of approximately 1 per million/year (1). It can be classified as familial, sporadic or infectious. It appears as a result of a conformational alteration of the neuronal prionic protein $\left(\operatorname{PrP}^{\mathrm{C}}\right)$, encoded in the PRNP gene on the chromosome 20. The polymorphism of methionine/valine on the codon 129 is the principal factor incriminated in the genesis of pathologic prion proteins. The conformational changes lead to neuronal loss and gliosis (2). The relation with amyloid deposits still remains unclear, given the presence of amyloid plaques in about $10 \%$ of cases (3). The clinical findings vary from psychiatric disorders to ataxia, extrapyramidal syndrome, visual disturbances, but a constant finding is a progressive dementia with a mean duration of 6 months (4). There is no treatment whatsoever and the progression is invariable to coma and death within several months.

\section{Case report}

We present the case of 64 years old male who was referred to our department for a progressive deterioration of the mental state appeared two months prior to presentation. The patient was previously hospitalized for psychotic symptoms. After 10 days he presented an abrupt mental status deterioration associated with myoclonus. Inward, the patient presented fluctuations of awareness, florid visual hallucinations, temporal and spatial disorientation and rapid mental decline. Neurologic examination showed pyramidal syndrome, extrapyramidal rigidity and primitive reflexes. Inconstant myoclonic jerks of the head and left limbs were observed spontaneously or triggered by noise. No relevant toxic metabolites were found in his blood. Magnetic resonance imaging (MRI) revealed marked atrophy and bilateral frontal lesions, FLAIR hyperintensities in fronto - parietal cortex and basal ganglia (Figure 1). A Video - EEG showed a specific encephalopatic pattern with triphasic, periodic slow wave complexes. Biochemistry showed normal blood values, negative human immunodeficiency virus (HIV), B and C type hepatitis viruses, normal glycaemia, negative syphilis serology (VDRL, TPHA); normal serum ions and no renal, hepatic and endocrine abnormalities were found. Cerebrospinal fluid (CSF) showed increased proteins $\left(0.51 \mathrm{~g} / \mathrm{L}-\right.$ max. $0.45 \mathrm{~g} / \mathrm{L}$ ), 6 cells $/ \mathrm{mm}^{3}$ (max. $2 / \mathrm{mm}^{3}$, lymphocytes and polymorphonuclear cells). Protein 14-3-3 was not analyzed due to unavailability at that time in the context of the rapid disease course. In spite of the supportive treatment the patient entered in a deep coma followed by cardio-respiratory failure, cardiac arrest and death. All data suggested a sporadic form of subacute spongiform encephalopathy according with the revised recommendation for CJD diagnostic criteria (5) (Table 1). Alzheimer disease, Lewy body dementia, metabolic or endocrine encephalopathies were excluded; progressive multifocal leukoencephalopathy is usually found in patient with immunodeficiency states or monoclonal antibodies treatment; herpes simplex, limbic and brainstem encephalitis were also ruled out. Autopsy was performed according to World Health Organization recommendations for suspected prion diseases (6). The personnel used protective, disposable clothing; contaminated surfaces were flooded in $2 \mathrm{M}$ of $\mathrm{NaOH}$ for one hour, and then rinsed with water. All biological waste was decontaminated by incineration. Macroscopic examination revealed mild cerebral edema and cortical atrophy. The brain was kept for 2 weeks in formalin fixation solution, with $96 \%$ formic acid for prion inactivation one hour before routine processing. After fixation, fragments were collected from all the lobes, basal ganglia and cerebellum. Microscopy: sections of $5 \mu \mathrm{m}$ thickness were stained with hematoxylin - eosin (HE), methyl violet and Congo red. HE stains showed non - inflammatory diffuse vacuolization with reactive gliosis (Figures 2, 3). Special stains have not revealed the presence of amyloid plaques. Due to unavailability, no im- 


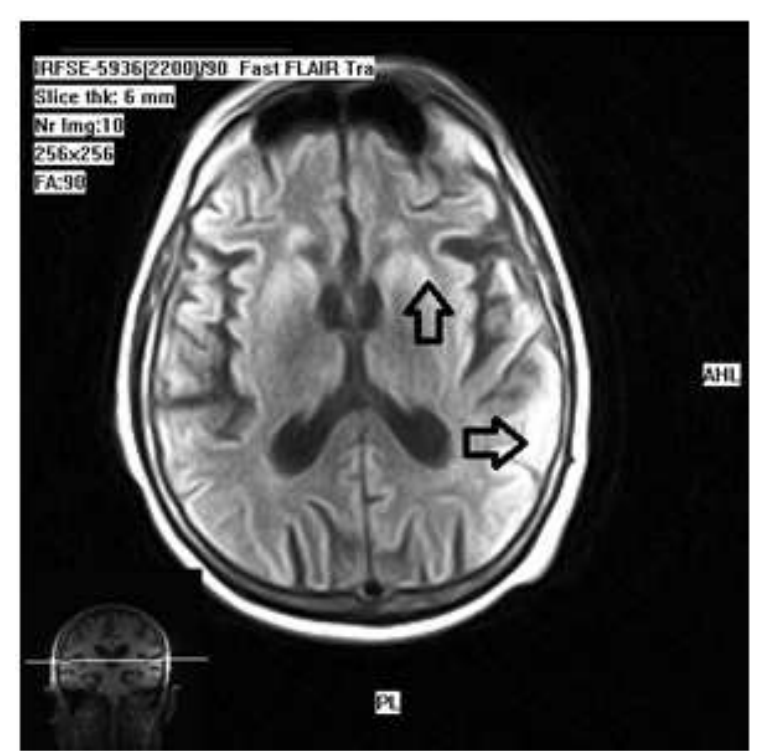

Figure 1. Axial FLAIR MRI showing temporal cortex and basal ganglia hyperintensities (arrows)

munostaining studies for scrapie prion isoform of $\operatorname{PrP}^{\mathrm{C}}\left(\mathrm{PrP}^{\mathrm{Sc}}\right)$ with antiprion monoclonal antibodies were performed. Neuropathological features were uniform with incipient spongiform changes in a relatively sparse distribution throughout the cerebral cortex. The evolution of signs and symptoms, MRI, EEG and autopsy exam sustained the diagnosis of subacute spongiform encephalopathy. This case report was approved by the local ethical committee.

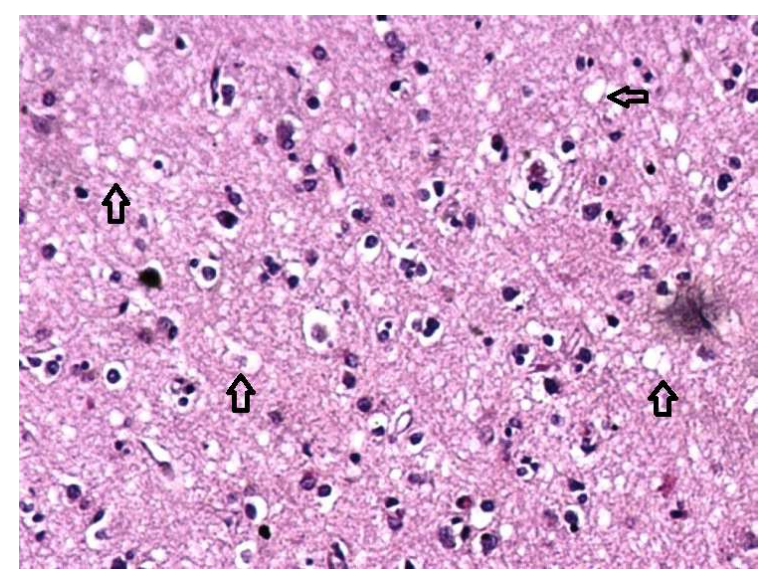

Figure 2. Astrogliosis and spongiform vacuolization in frontal cortex (black arrows); hematoxylin - eosin stain with $100 x$ magnification

\section{Discussions}

This case is included in the classic type of sporadic CJD. Usually the symptoms occur between 50 and 70 years of age. The mean duration of the disease is considered to be 6 months. However, there are reports about acute forms with duration of several weeks, or with a very long duration up to 2 years and a half (7). The revised criteria must be used whenever a rapid demential syndrome is observed, this could identify probable or possible cases that could be overviewed or mistaken with other subacute encephalopathies $(5,8)$.

The limitation of this case report was the lack of specific biomarkers. The need of a precise diagnostic must overcome the unavailability of some expensive or hard-to-reach procedures. Next, we discuss the role of the most important modern biomarkers in the completion of CJD diagnosis. The $\mathrm{PrP}^{\mathrm{Sc}}$ is the result of a conformational alteration from $\alpha$-helical to $\beta$-sheet of the common prionic protein $\left(\operatorname{PrP}^{\mathrm{C}}\right)$, which is encoded in the PRNP gene on the chromosome 20 (3). There are several subtypes of $\operatorname{PrP}^{\mathrm{Sc}}$ isoform derived from the protease-resistant fragments following the proteolytic processes. Types 1 and 2 are characteristic for CJD. The polymorphism methionine/valine $(\mathrm{M} / \mathrm{V})$ on the codon 129 of PRNP gene can further on subtype the isoforms in MM, MV

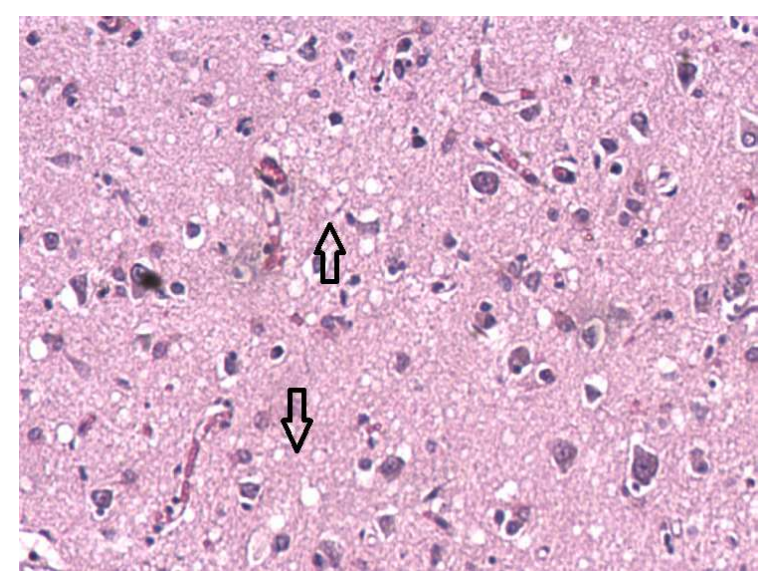

Figure 3. Astrogliosis and incipient spongiform vacuolization in the temporal cortex (black arrows); hematoxylin - eosin stain with 100x magnification. 
Table 1. Diagnostic criteria for CJD (after Zerr, 2009)

\begin{tabular}{|c|c|}
\hline Definite CJD & $\begin{array}{l}\text { Diagnosed by standard neuropathological techniques; and/or immunocytochemically; and/or } \\
\text { Western Blot confirmed protease-resistant PrP; and/or presence of scrapie-associated fibrils }\end{array}$ \\
\hline Probable CJD & 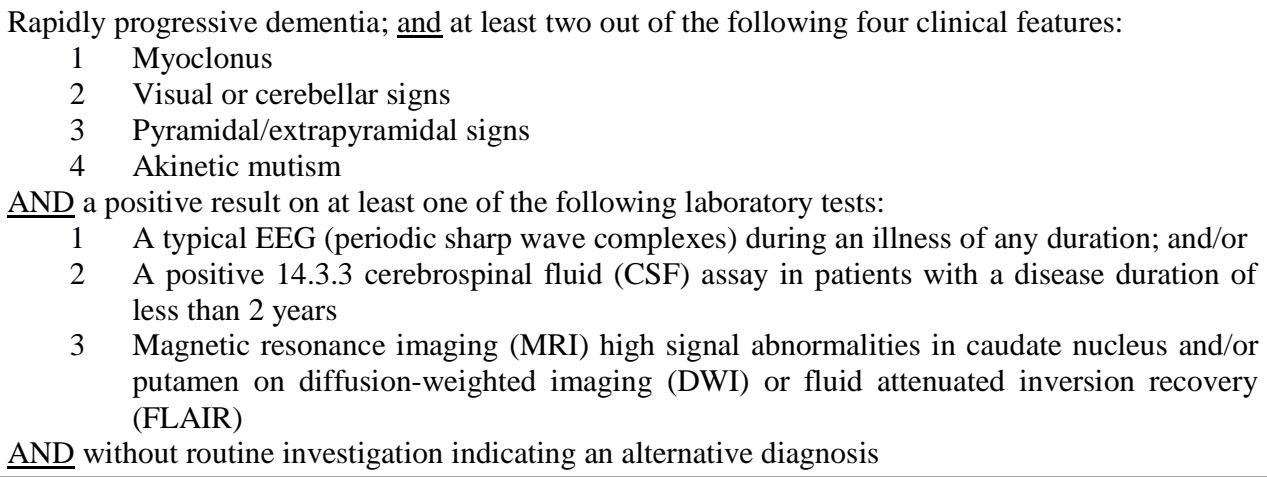 \\
\hline Possible CJD & $\begin{array}{l}\text { Progressive dementia; and at least two out of the following clinical features: } \\
1 \text { Myoclonus } \\
2 \text { Visual or cerebellar signs } \\
3 \text { Pyramidal/extrapyramidal signs } \\
4 \text { Akinetic mutism } \\
\text { AND the absence of a positive result for any of the three laboratory tests that would classify a case } \\
\text { as "probable" (see tests } 1-3 \text { above) } \\
\text { AND duration of illness less than two years } \\
\text { AND without routine investigation indicating an alternative diagnosis }\end{array}$ \\
\hline
\end{tabular}

and VV. The typical sporadic forms are usually type $1 \mathrm{MM}$ homozygous and MV heterozygous (2). The conformational change in $\beta$-sheet confers protein kinase resistance which leads in the end to neuronal loss and gliosis. Some suggest the involvement of an unknown protein called "protein $X$ ", a supposed chaperon protein as enhancer of endoproteolytic cleavage of $\operatorname{PrP}^{\mathrm{C}}$ to $\operatorname{PrP}^{\mathrm{Sc}}$ (9). Similarities to this kind of conformational change were observed at $\alpha$-synuclein which is found in Parkinson's disease. This protein is found to have $\alpha$-helix form, but in unknown circumstances it undergoes a transition to $\beta$-sheet structure that can lead to accumulation of amyloid plaques in the end. (10). The hypothesis that $\alpha$-synuclein is a prion-like protein is sustained also by the fact that $\operatorname{PrP}^{\mathrm{Sc}}$ specific antibodies can bind to $\alpha$-synuclein and amyloid oligomers (11). In the late years, significant progress was made regarding the ante mortem diagnosis of CJD. CSF analysis is mandatory to rule out other causes of encephalopath- ies such as infections of CNS, autoimmune or other neurodegenerative disorders. The cerebrospinal fluid 14-3-3 protein is a regulatory protein expressed in all cells with a role of binding signaling proteins as kinases and transmembranare receptors (12). It is found predominantly in the CSF of patients with CJD but high levels are found in other neurodegenerative disorders. Protein 14-3-3 is found positive in $95 \%$ of the patient with CJD. The disadvantage is that it may be found in other types of dementia as Alzheimer disease and in different encephalitides (13). Beaudry et al. find a sensitivity of $89.8 \%$ and specificity for CJD of $100 \%$ (14). Other CSF biomarkers useful in the diagnosis of CJD are S-100 protein, neuron-specific enolase and tau-protein. $\mathrm{S}-100$ protein is an astroglial protein found with a higher sensitivity than 14-3-3 but with a smaller specificity $(85.4 \%)$.

Neuron - specific enolase is another biomarker useful in the diagnosis of CJD but 
with a sensitivity and specificity inferior to 14 3-3 protein. Tau protein is a reliable biomarker of axonal injury. The role of tau protein is thought to be that of stabilizing the microtubules in the structure of the axon $(13,15)$. Degenerative lesions (as beta-amyloid toxicity) induce hypephosphorilation and formation of neurofibrillary tangles. CSF tau levels are high in CJD and can be used as an additional marker along with 14-3-3. Specificity of tau is low given the fact that almost all neurodegenerative disorders express high tau protein in CSF. The relationship between prion, amyloid toxicity and tau phosphorylation appears straightforward in some cohort studies of sporadic CJD (15). Some authors decline the actual utility for 14-3-3 and tau protein given the fact that these biomarkers can be inconstantly found in other neurodegenerative and inflammatory diseases such as progressive multifocal leukoenchephalopathy, herpes simplex encephalitis, HIV-Dementia complex, Hashimoto's encephalopathy, primary lymphomas of CNS $(16,17)$. But in addition to these biomarkers, specific laboratory analysis should exclude other diagnoses. Progressive multifocal leukoencephalopathy can be tested through JC virus PCR testing in CSF (positive test with appropriate clinical symptoms and MRI strongly supports the diagnosis), a CSF panel for viral encephalitis excluding especially herpes simplex, varicella, rubella encephalitis (18). HIV, neuroborreliosis and syphilis tests are mandatory, as oligoclonal bands and immunologic panel for multiple sclerosis and CNS vasculitides. The importance of these tests is the accuracy of diagnosis in order to treat the potential reversible encephalopathies. In latter years, immunoprecipitantion and western blot use anti-prion antibodies in order to have a more accurate diagnosis (10). In addition to CSF and serologic findings, the cerebral MRI and EEG increase the rate of correct diagnosis $(19,20)$. Histopathology represents the only method to certify the diagnosis of CJD. Instead of brain biopsy, which can result in serious complication, autopsy remains the preferred method for collecting brain tissue (21). The classic pathology of sporadic CJD is represented by massive neuronophagia with vacuolization (spongiform degeneration) and reactive astrocyte proliferation. Sporadic form of CJD usually does not form amyloidal plaques (more characteristic for the variant type), but these can be found in approximately $10 \%(3,22)$. Immunostaining for prion protein and western blot confirmation for protease-resistant prion protein increase the accuracy of correct diagnosis (23, 24). Prion diseases are potentially transmissible mostly through cerebrospinal fluid and nervous tissue and it is amount dependent. A recent study showed a risk of oral transmission of the soil-bound prions, suggesting that prions can be viable in some types of soil contributing to the environmental spread (25). Special care must be taken for all potentially infectious biological material, for reprocessing surgical instruments as World Heath Organization CJD infectious control guidelines recommend (6).

\section{Conclusions}

In this report we presented a case of sporadic CJD with subacute evolution, diagnosed in clinical, imagistic and neurophysiological ground with histopathology confirmation.

\section{References}

1. Prusiner SB, Neurodegenerative diseases and prions, N Engl J Med. 2001;344:1516-26.

2. Gambetti P, Kong Q, Zou W, Parchi P, G Chen SG, Sporadic and familial CJD: classification and characterization, British Medical Bulletin. 2003;66, 214.

3. Sadowski M, Verma A, Wisniewski T, Chapter 59. Infectious of the nervous system. Prion Diseases, in Bradley WG, Daroff RB, Fenichel GM, Jankovic J, Neurology in clinical practice, Elsevier. 2004;II:1616-17.

4. Beauvais $\mathrm{P}$, Billette de Villemeur $\mathrm{T}$, Maladie à prion ou encéphalopathies spongiformes transmissibles, Encyclopédie medico - chirurgicale. 17-056-a-40:10-14. 5. Zerr I, Kallenberg K, Summers DM, Romero C, Taratuto A, Heidemann U et al., Updated Clinical Diagnostic Criteria for Sporadic Creutzfeldt - Jakob disease, 
Brain 2009;132:2659-2668.

6. WHO Infection Control Guidelines for Transmissible Encephalopathies Geneva, Switzerland, 1999: who.int/csr/publication/bse/who_cds_csr_aph_2000_3/en. 7. Javed Q, Alam FS., Jaganathan G, An unusual case of sporadic Creutzfeldt-Jakob disease (CJD), BMJ Case Rep. 2010;PMCID: PMC3047567.

8. Jansen C, Parchi P, Capellari S, Human HYPERLINK "http://www.ncbi.nlm.nih.gov/pubmed/22558438"prionHYPERLINK

"http://www.ncbi.nlm.nih.gov/pubmed/22558438" diseases in the Netherlands (1998-2009): clinical, genetic and molecular aspects, PLoS One. 2012;7(4):e36333; PMID:22558438.

9. Hachiya NS, Imagawa M, Kaneko, K, The possible role of protein $\mathrm{X}$, a putative auxiliary factor in pathological prion replication, in regulating a physiological endoproteolytic cleavage of cellular prion protein. Med. Hypotheses, 2007;68(3):670-63.

10. Olanow CW, Brundin P, Parkinson's disease and alpha synuclein: is Parkinson's disease a prion-like disorder?, Mov Disord, 2013;28:3140.doi: $10.1002 / \mathrm{mds} .25373$.

11. Tayebi M, Jones DR, Taylor WA, Stileman BF, Chapman C, Zhao D, David M, PrPSc-Specific Antibodies with the Ability to Immunodetect Prion Oligomers, PLoS ONE 2011;6(5): e19998. doi:10.1371/journal.pone.0019998.

12. Obsil T, Ghirlando R, Klein DC, Ganguly S, Dyda F. Crystal structure of the 14-3-3 zeta: serotonin N-acetyltransferase complex. A role for scaffolding in enzyme regulation, Cell 2001, Apr 20;105(2):257-67.

13. Baert LA, Knauth M, Inflammatory Diseases of the Brain, Springer 2009:113-123.

14. Beaudry P, Cohen P, Brandel JP, Delasnerie Lauprêtre N, Richard S, Launay JM, Laplanche JL, 14-3-3 protein, neuron specific enolase and S-100 protein in cerebrospinal fluid of patients with Creutzfeldt-Jakob disease, Dement Geriatr Cogn Disorder. 1999 JanFeb;10(1):40-6.

15. Reiniger L, Lukic A, Linehan J, Rudge P, Colinge J, Mead S, Bradner S, Tau, prions and A $\beta$ : the triad of neuro- degeneration, Acta Neuropathol. 2011 Jan;121(1):5-20. 16. Vander T, Hallevy T, Alsaed I, Valdman S, Ifergane G, Wirguin I, 14-3-3 protein in the CSF of a patient with Hashimoto's encephalopathy, J Neurol. 2004 Oct; 251(10):1273-1274.

17. Süssmuth SD, Hansoto R, Tumani H, Tau protein in CSF: a blood-CSF barrier related evaluation in patients with various neurological diseases, Neuroscience Letters, 2001; 300:95-98.

18. Ferenczy MW, Marshall LJ, Nelson CD, Atwood WJ, Nath A, Khalili K, Major EO, Molecular biology, epidemiology and pathogenesis of progressive multifocal leukoencephalopathy, the JC virus-induced demyelinating disease of the brain. Clin Microbiol Rev. 2012 Jul;25(3):471-506. doi:10.1128/CMR.0503-11.

19. Schröter A, Zerr I, Henkel K, Tschampa HJ Finkelstaedt M, Poser S, Magnetic resonance imaging in diagnosis of Creutzfeldt-Jakob disease, Arch Neurol 2000;57:1751-1757.

20. Zerr I, Pocchiari M, Collins S, Brandel JP, de Pedro Cuesta J, Knight RS, et al. Analysis of EEG and proteins as aids to the diagnosis of Creutzfeldt-Jakob disease, Neurology 2000;55:811-815.

21. Louie JK, Gavali SS, Belay ED, Trevejo R, Hammond LH, Schonberger LB, et al. Barriers to CreutzfeldtJakob disease autopsies, California. Emerg Infect Dis. 2004 Sep; 10(9): 1677-80.

22. Ironside JW, Head M, Neuropathology and molecular biology of variant Creutzfeldt-Jakob disease, Curr Top Microbiol Immunol 2004;284:133-59.

23. Kovács GG, Majtényi K, László L, Prion protein immunohistochemistry in Creutzfeldt-Jakob disease, Pathol Oncol Res 1997 Sep 3(3):193-7.

24. Tschampa JH, Herms J, Schultz-Schaeffer WJ, Maruschak B, Windl O, Jastrow U, et al., Clinical findings in sporadic Creutzfeldt-Jakob disease correlate with thalamic pathology, Brain 2002;125(11):2558-66.

25. Johnson CJ, Pedersen JA, Chappell RJ, McKenzie D, Aiken JM, Oral Transmissibility of Prion Disease Is Enhanced by Binding to Soil Particles, PLoS Pathog, 2007;3(7): e93. doi:10.1371/journal.ppat.0030093. 